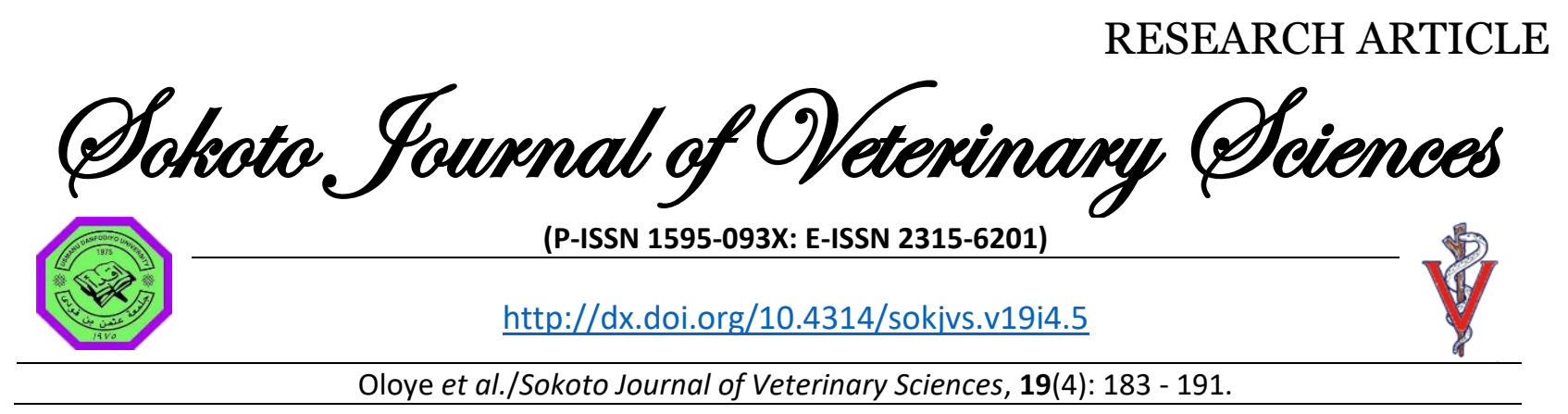

\title{
Assessment of mango and carrot juices as West African Dwarf ram semen extender at room temperature
}

\author{
AA Oloye, AA Fakile, SA Olurode, L Mustapha*, AP Bassahwa \& AS \\ Adetomiwa \\ Department of Veterinary Surgery and Theriogenology, College of Veterinary Medicine, Federal University of \\ Agriculture Abeokuta, Nigeria
}

*Correspondence: Tel.: +2347069594494; E-mail: mustaphal@funaab.edu.ng

\begin{abstract}
Copyright: (c) 2021
Oloye et al. This is an open-access article published under the terms of the Creative Commons Attribution License which permits unrestricted use, distribution, and reproduction in any medium, provided the original author and source are credited.
\end{abstract}

Publication History: Received: 08-03-2021 Revised: 08-08-2021 Accepted: 12-08-2021

\section{Abstract}

Quality and affordable semen extenders are essential for successful artificial insemination. Extenders from natural sources have been found to be effective and affordable. Using two matured West African Dwarf rams $(18.67 \pm 1.45 \mathrm{~kg})$, the effectiveness of graded mixtures of mango and carrot juices (100\% Mango (M), 100\% Carrot (C) $90 \% \mathrm{M} 10 \% \mathrm{C}, 70 \% \mathrm{M} 30 \% \mathrm{C}, 50 \% \mathrm{M} 50 \% \mathrm{C}, 30 \% \mathrm{M} 70 \% \mathrm{C}$ and $10 \% \mathrm{M} 90 \% \mathrm{C}$ ), and conventional egg yolk citrate (EYC) as ram semen extender was studied. Each diluent was constituted in five aliquots using standard methods and $\mathrm{pH}$ determined electronically. Semen collection in three trials using electro-ejaculator method was followed by evaluation for colour, volume, pre-extended sperm motility, concentration, percentage liveability and morphological normality. Thereafter, semen were extended with different diluents by adding $0.2 \mathrm{ml}$ of semen to $7.5 \mathrm{ml}$ of diluents. Immediately, hourly evaluation for sperm motility from zero to eight hours then twenty-four hours post-extension was done. Diluents revealed in the study as the most effective semen extender were subjected to proximate analyses. The $\mathrm{pH}$ of the diluents ranged from $4.56 \pm 0.11(70 \% \mathrm{M} 30 \% \mathrm{C})$ to $6.40 \pm 0.14(90 \% \mathrm{C} 10 \% \mathrm{M})$. The mean ejaculate volume was $0.8 \pm 0.00 \mathrm{ml}$ while colour observed was creamy. The pre-extended mean spermatozoa motility, morphological abnormality, percentage liveability and concentration were $94.5 \pm 4.5 \%, \quad 7.0 \pm 2.83 \%, 88.75 \pm 2.5 \%$ and $0.3 \times 10^{9}$ sperm cell $/ \mathrm{ml}$ respectively. Spermatozoa motility declined progressively in all the diluents from 0-24hours postextension. The decline was observed to be significantly rapid ( $p \leq 0.05$ ) in $100 \%$ Carrot diluent from $94 \pm 2.4 \%$ at zero hour to $0 \%$ at three hours post extension. Only diluents $90 \% \mathrm{M} 10 \% \mathrm{C}, 100 \% \mathrm{M}$ and Egg Yolk Citrate provided sperm motility score of $30 \%$ and above at eight hours post extension. Proximate analyses of $90 \% \mathrm{M} 10 \% \mathrm{C}$ and $100 \% \mathrm{M}$ revealed presence of essential minerals which are found to be naturally occurring in ram ejaculate. The work established that mixture of mango and carrot $(90 \% \mathrm{M} 10 \% \mathrm{C})$ and $100 \%$ mango juices could be used as a suitable semen extender in preserving West African Ram semen at room temperature.

Keywords: Carrot, Egg-yolk, Mango, Ram, Semen extender 


\section{Introduction}

Sheep plays important economic and cultural roles in the livelihood of both rural and urban dwellers of Nigeria and other West African states (Dossa et al., 2015). With small body size, high productive capacity and rapid growth rates, sheep are ideally suited for production by resource poor small holders. Semen quality is one of the most valuable indicators of male reproductive health (Alesia, 2013; Oloye et al., 2019) and the physical characteristics of the seminal fluid can affect its fertility (Ogbuewu, 2008). Rams reach puberty at $5-7$ months of age at $50-60 \%$ of their mature body weight. The average volume of ram semen is $1.0 \mathrm{ml}(0.5-2.0 \mathrm{ml})$ and it is non-fractionated. Average sperm concentration $\left(\times 10^{6} / \mathrm{ml}\right)$ is 2000 (1250-3000). The average motility (\%) is 90 and average normal spermatozoa (\%) is 85 (Noakes \& Parkison, 2001). The $\mathrm{pH}$ of ram semen containing normal numbers of spermatozoa is 6.9 or less (Loubser \& Van Niekerk, 1983). Artificial Insemination is one of the important management tools for optimizing the production performance and maximizing the use of high value rams even by small farmers who don't have breeding rams (Kumar \& Naqvi, 2010). However, to gain these advantages in West African Dwarf ram production, the ram semen will require proper processing including collection, extension and storage (Oloye et al., 2019). Semen extension is made possible through the use of semen extenders which are liquid diluents that are added to semen to preserve its fertilizing ability. It acts as a buffer to protect the sperm from their own toxic byproducts and it protects the sperm cells from cold and osmotic shocks during chilling and freezing process. It guarantees increase in the rate of genetic improvement, reduce cost of maintaining male animals and allow several female animals to be bred at the same time through the use of estrus synchronization (Smith, 2003).

These extenders must therefore possess the ability to shield the spermatozoa against cold shock, microbial attack, provide energy and buffer (Oloye et al., 2008). They must be easily accessible and affordable especially for the peasant sheep breeders, a condition well satisfied by natural semen extenders. The different types of these natural extenders are egg yolk medium, pawpaw juice medium, coconut milk medium and tomato juice medium (Oloye et al., 2019). Kusum et al. (2018) reported that egg yolk comprises of $51.1 \%$ water, $16 \%$ protein, $30.6 \%$ fat, $1.7 \%$ mineral following chemical analysis of an egg. As semen extenders, the egg-yolk citrate has been known to minimize the adverse effect of low temperatures and provide protection to the sperm during cooling (Katila et al., 1997). Mango (Mangifera indica) is a member of the Anacardiaceae family which comprises of more than 70 genera. (Mukherjee \& Litz, 2009). Mango is a tropical fruit grown in about 85 countries in the tropics and developing countries (such as Nigeria). It is rich in antioxidants, vitamins, minerals and phytonutrients (Zafar \& Sidhu, 2017) all of which are important for fertility because of their role in hormonal and acid- alkaline balance which are necessary for gamete health. Carrot (Daucus sativus) is a root vegetable, usually orange in colour, although purple, black, yellow, red and white cultivars exist (Singh et al., 2018) and is largely cultivated in the Northern part of Nigeria such as Zaria, Kano, Sokoto and Jos. It is a good source of carotenoids, flavonoids, polyacetylenes, vitamins, and minerals, all of which possess numerous nutritional and health benefits ( $\mathrm{da}$ Silva Dias, 2014). Nouri et al. (2009) reported that carrot seed extract induces spermatogenesis following gentamicin toxicity probably mainly through the elevation of testosterone levels. Ewuola \& Odefemi (2019) also reported increase sperm reserve and increase daily sperm production following the administration of carrot fruit extract to rabbit buck. Carrot and mango juices are readily available in our climate and are quite cheap, especially when in season. They contain essential minerals that may boost spermatozoa health by aiding motility and improving viability and could be an appropriate alternative to conventional egg yolk citrate which has the disadvantage of causing clumping or agglutination of spermatozoa when used as semen extender. This work, therefore, examined the suitability of graded mixture of mango juice and carrot juice and compare with egg yolk citrate at room temperature $\left(24^{\circ} \mathrm{C}\right)$.

\section{Materials and Methods}

Two matured West African Dwarf rams $(18.67 \pm 1.45 \mathrm{~kg})$ were use for the study. They were acclimatized and given prophylactic treatment.

Semen collection and Pre- extended semen evaluation Fresh semen was collected through the electroejaculator method once per week for three weeks and pooled. Sperm concentration, Sperm motility, sperm morphology and the life dead ratio of the sperm in the semen collected were evaluated immediately using method described by Zemjanis (1977).

To evaluate motility of sperms cells, a drop of semen was placed on a pre-warmed glass slide and viewed under $\times 40$ objective lens using a light microscope 
(Zemjanis, 1977). The motility was then scored according to the scale presented in Table 1 credited to Singh (2005).

To evaluate sperm morphology, 5-6 drops of Eosinnigrosin was placed on a clean glass slide; a drop of semen was added into the stain and stirred with a glass rod. After one minute, then a smear was made on a clean glass slide. The smear was examined after air drying. Individual spermatozoa were examined at $\times 1000$ magnification under oil immersion under the microscope. Deviations from the normal contours of the head, attachment of midpiece and tail was observed. At least 400 spermatozoa were observed in different fields and the defects categorized into head, mid-piece and tail defects (Singh, 2005)

The concentration of the spermatozoa was estimated by diluting $25 \mu \mathrm{l}$ semen into $5.0 \mathrm{ml}$ distilled water then pipetting $15 \mu \mathrm{l}$ of the solution into each chamber of a Neuberhaemocytometer (Karagiannidis et al., 2000; Kheramand et al., 2006).

The live/dead ratio was evaluated with the Eosinnigrosin staining technique in which 5-6 drops of the eosin-nigrosin stain was placed on a clean glass slide, followed by a drop of semen mixed with the stain carefully. A smear was made on a clean glass slide and examined after drying.

The diagnostic feature for live and dead is that the dead spermatozoa absorb the stain and look pink while the live spermatozoa do not absorb the stain and look white or unstained. A total of 300 spermatozoa were counted from different fields (Singh, 2005).

\section{Buffer preparation}

Trisodium citrate dehydrate $(2.9 \mathrm{gm})$ was dissolved in $100 \mathrm{ml}$ of distilled water. This was thoroughly stirred until the solution was completely dissolved in the solvent (Oloye et al., 2019).

\section{Extension media preparation}

Egg yolk citrate: The intact egg was thoroughly washed with distilled water and disinfected with an antiseptic agent. The egg was gently cracked at the tip and the egg yolk was manually and carefully separated from the albumen. It was stirred with a stirrer until a homogenous mixture was gotten. $40 \mathrm{mls}$ of citrate was added to $10 \mathrm{mls}$ of the egg yolk to constitute $80 \%$ citrate: $20 \%$ egg yolk. $0.5 \mathrm{ml}$ penicillinstreptomycin preparation was added to the extender.

Mango juice: The mango was washed with distilled water, skin was peeled, and then, the flesh was sliced and blended until a fairly smooth consistency was achieved. It was sieved using a sterilized cotton material squeeze out the juice. Three fresh mango fruits were utilized at each preparation.

Carrot juice: The carrot was washed, cut into bits, grated and blended. The juice was squeezed out through a sterile sieved made from sterilized cotton material. 10-20 fresh carrots was utilized at each preparation depending on their size.

Graded mango-carrot mixture preparation: This was constituted as presented in Table 2.

To each of the mixture, sodium citrate was added at a ratio of $20 \%$ mixture: $80 \%$ citrate. $0.5 \mathrm{ml}$ of penicillinstreptomycin preparation, $v / v$, was added to each extender.

$\mathrm{pH}$ Evaluation: The $\mathrm{pH}$ of the diluents was measured after constitution using electronic (Metler ${ }^{\circledR} \mathrm{PHS}-3 \mathrm{C}$ ) $\mathrm{pH}$ meter.

Extension and storage

To each graded mixture diluents, and the yolk sodium

Table 1: Markers for sperm motility grading (Singh, 2005)

\begin{tabular}{lll}
\hline Grade & Movement of spermatozoa & Percentage of motile spermatozoa \\
\hline 0 & Nil & Nil \\
0.5 & Very weak & 10 \\
1.0 & Oscillatory movement & 20 \\
1.5 & Rapid & 30 \\
2.0 & Fair rapid and vigorous & 40 \\
2.5 & Rapid vigorous and progressive & 50 \\
3.0 & Good, very rapid and vigorously progressive & 60 \\
3.5 & Most vigorous, progressive and active & 70 \\
4.0 & Very good, most vigorous with progressive swirling activity & 80 \\
4.5 & Highly vigorous and progressive with slight waves and full activity & 90 \\
5.0 & Excellent, highly vigorous progressive and waves in all directions & 100 \\
\hline
\end{tabular}


citrate, fresh semen was added at a rate of $0.2 \mathrm{ml}$ of semen to $7.5 \mathrm{ml}$ of diluents.

\section{Extended semen evaluation}

A drop of extended semen was placed on a sterile slide. The slide was examined for sperm motility using method described by Zemjanis (1977). The evaluation was carried out at $0,1,2,3,4,5,6,7,8$ and 24 hours of storage at room temperature.

\section{Statistical analysis}

Descriptive statistical analysis was used. Mean and standard error of the mean were calculated. Differences of mean was compared using one way Analysis of Variance (ANOVA). Tukey multiple comparison was used to separate significant mean scores at confidence level of $95 \%$.

\section{Results}

The mean $\mathrm{pH}$ of the diluents: $100 \%$ Mango (M), 100\% Carrot (C), 90\%M10\%C, 90\%C10\%M, 70\%M30\%, $30 \% \mathrm{M} 70 \% \mathrm{C}, 50 \% \mathrm{M} 50 \% \mathrm{C}$, were $5.68 \pm 0.05,6.39 \pm 0.06$, $5.57 \pm 0.18,6.40 \pm 0.14,4.56 \pm 0.11,5.39 \pm 0.05$ and $5.80 \pm 0.05$ respectively (Table 3 ). The mean ejaculate volume was $0.8 \pm 0.00 \mathrm{ml}$. The semen colour observed was creamy. The mean pre-extended spermatozoa motility, percentage morphological abnormalities, concentration and percentage liveability were $94.5 \pm 4.5 \%, 7.0 \pm 2.83 \%, 0.3 \times 10^{9}$ spermatozoa $/ \mathrm{ml}$ and $88.75 \pm 2.5 \%$ respectively (Table 4 ). The spermatozoal morphological abnormalities cut across the head, midpiece and tail of the spermatozoa (Table 5).

Table 2: Graded mango-carrot juice mixtures

\begin{tabular}{lll}
\hline Diluents & Mango juice\% & Carrot juice\% \\
\hline 1 & 10 & 90 \\
2 & 30 & 70 \\
3 & 50 & 50 \\
4 & 70 & 30 \\
5 & 90 & 10 \\
6 & 100 & 0 \\
7 & 0 & 100 \\
\hline
\end{tabular}

Table 3: Mean $\mathrm{pH}$ values of Diluents $(n=5)$

\begin{tabular}{llllllll}
\hline $\begin{array}{l}\text { Diluents+ } \\
\text { buffer }\end{array}$ & $100 \% \mathrm{M}$ & $100 \% \mathrm{C}$ & $90 \% \mathrm{M} 10 \% \mathrm{C}$ & $90 \% \mathrm{C} 10 \% \mathrm{M}$ & $70 \% \mathrm{M} 30 \% \mathrm{C}$ & $70 \% \mathrm{C} 30 \% \mathrm{M}$ & $50 \% \mathrm{M} \mathrm{50 \% C}$ \\
\hline $\mathrm{pH}$ & $5.68 \pm 0.05$ & $6.39 \pm 0.06$ & $5.57 \pm 0.18$ & $6.40 \pm 0.14$ & $4.56 \pm 0.11$ & $5.39 \pm 0.05$ & $5.80 \pm 0.05$ \\
\hline
\end{tabular}

Table 4: Pre-extension spermatozoa characteristics $(n=2)$

\begin{tabular}{lllll}
\hline $\begin{array}{l}\text { Sperm } \\
\text { Characteristics }\end{array}$ & $\begin{array}{l}\text { Sperm Motility } \\
(\%)\end{array}$ & $\begin{array}{l}\text { Sperm Concentration } \\
(\text { Sperm cell/ml) }\end{array}$ & $\begin{array}{l}\text { Percentage Morphological } \\
\text { abnormalities }\end{array}$ & $\begin{array}{l}\text { Percentage spermatozoa } \\
\text { liveability }\end{array}$ \\
\hline Mean \pm SD & $94.5 \pm 4.5 \%$, & $0.3 \times 10^{9}$ & $7.0 \pm 2.83 \%$, & $88.75 \pm 2.5 \%$ \\
\hline
\end{tabular}

Table 5: Mean pre-extended spermatozoa morphological abnormalities

\begin{tabular}{lllllllllll}
\hline & FT & FH & BT & CT & DwT & ACD & MPB & $\begin{array}{l}\text { Total number of } \\
\text { spermatozoa }\end{array}$ & $\begin{array}{l}\text { Total Abnormal } \\
\text { sperm cells }\end{array}$ & $\begin{array}{l}\text { Normal sperm } \\
\text { cells }\end{array}$ \\
\hline Trial 1 & 2 & 6 & 1 & 0 & 0 & 0 & 0 & 100 & $91(91 \%)$ & $9(9 \%)$ \\
Trial 2 & 3 & 1 & 0 & 0 & 0 & 1 & 0 & 100 & $5(5 \%)$ & $95(95 \%)$ \\
Mean \pm SD & $2.5 \pm$ & $3.5 \pm$ & $0.5 \pm$ & $0.0 \pm$ & $0.0 \pm$ & $0.5 \pm 0$. & $0.0 \pm$ & $100 \pm 0.0$ & $7.0 \pm 2.83$ & $93.0 \pm 2.83$ \\
& 0.71 & 3.53 & 0.71 & 0.0 & 0.0 & 71 & 0.0 & & $(7.0 \pm 2.83 \%)$ & $(93.0 \pm 2.83 \%)$ \\
\hline
\end{tabular}

KEYS: FT: Free tail (Headless); FH: Free head (Tailess); BT: Bent tail; CT: Coiled tail; DwT: Dwarf tail; AcD: Acrosomal defects and MPB: Mid-piece Bent 
At zero hour post extension, 30\%M 70\%C had a significantly lower motility score of $74 \pm 19$. $17 \%$ compared to Egg yolk citrate $(99.6 \pm 0.55 \%)$ which gave the highest score, $50 \% \mathrm{M} 50 \% \mathrm{C}(89 \pm 2.24 \%)$ and $100 \% \mathrm{C}(94 \pm 2.24 \%)(\mathrm{p} \leq 0.05)$.

At one hour post extension, motility score of $100 \% \mathrm{C}$ group had reduced to $31 \pm 2.24 \%$ and was significant compared to EYC (98 $\pm 1.20 \%), \quad 30 \% \mathrm{M} \quad 70 \% \mathrm{C}$

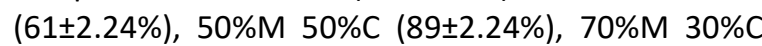

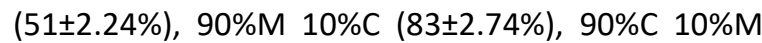
$(49 \pm 2.24 \%)$ and $100 \% \mathrm{M}(81 \pm 2.24 \%)$ at $\mathrm{p} \leq 0.05$. The score of $100 \% \mathrm{C}$ group further reduced at two hours post extension to $11 \pm 2.24 \%$ significantly when compared with EYC $(95 \pm 1.79 \%), 30 \% \mathrm{M} \quad 70 \% \mathrm{C}$ (68 $\pm 5.70 \%), 70 \% \mathrm{M} \mathrm{30 \% C} \mathrm{(50 \pm 3.54 \% ),} \mathrm{50 \% M} \mathrm{50 \% C}$ $(88 \pm 2.74 \%), \quad 100 \% \mathrm{M} \quad(50 \pm 3.54 \%), \quad 90 \% \mathrm{M} \quad 10 \% \mathrm{C}$ $(80 \pm 0.00 \%)$ and $90 \% \mathrm{C} 10 \% \mathrm{M}(50 \pm 3.54 \%)(\mathrm{p} \leq 0.05$.

At three hours post extension, $100 \% \mathrm{C}$ motility score had become $0 \%$ compared to EYC $(94 \pm 3.19 \%), 30 \% \mathrm{M}$
$70 \% \mathrm{C}(40 \pm 3.54 \%), 70 \% \mathrm{M} 30 \% \mathrm{C}(46 \pm 2.24 \%), 50 \% \mathrm{M}$ $50 \% \mathrm{C}(73 \pm 2.74 \%), 100 \% \mathrm{M}(50 \pm 3.54 \%), 90 \% \mathrm{M} \mathrm{10 \% C}$ $(45 \pm 0.00 \%)$ and $90 \% \mathrm{C} 10 \% \mathrm{M}(30 \pm 3.54 \%)$ ( $\mathrm{p} \leq 0.05$.) At four hours post extension, EYC had the highest motility score $(93 \pm 2.74 \%)$ followed by $90 \% \mathrm{M} 10 \% \mathrm{C}$ $(59 \pm 5.48)$ and both were significantly different from other diluents when compared with them. This trend repeated itself at five hours, six hours, seven hours and eight hours post extension.

At twenty-four hours post extension, EYC motility score had reduced to $31 \pm 2.24 \%$ and was significantly different from all other diluents, while $90 \% \mathrm{M} 10 \% \mathrm{C}$ had a motility score of $9.6 \pm 1.01 \%$ that was significantly different compared with the other diluents except EYC.

Proximate analysis done for the best diluent combination $(90 \% \mathrm{M} 10 \% \mathrm{C})$ and $100 \% \mathrm{M}$ revealed $5.17 \pm 0.00 \%$ and $15.84 \pm 0.099 \%$ carbohydrate content respectively (Table 6).

Table 6: Proximate analysis of 100\%M 90\%M 10\%C

\begin{tabular}{llllllllll}
\hline S/n & Diluent & Trials & MC\% & Dry matter & Ash\% & Fat\% & CF\% & CP\% & CHO\% \\
\hline 1 & $100 \% M$ & $1^{\text {st }}$ & 75.47 & 24.53 & 1.93 & 1.40 & 0.09 & 5.25 & 15.91 \\
& & $2^{\text {nd }}$ & 75.45 & 24.55 & 1.99 & 1.42 & 0.10 & 5.27 \\
& & Mean & $75.46 \pm 0.014$ & $24.54 \pm 0.014$ & $1.96 \pm 0.042$ & $1.41 \pm 0.014$ & $0.095 \pm 0.007$ & $5.26 \pm 0.014$ & $15.84 \pm 0.099$ \\
2 & $90 \% M 10$ & $1^{\text {st }}$ & 93.41 & 6.59 & 0.18 & 0.10 & 0.02 & 1.12 & 5.17 \\
& \%C & $2^{\text {nd }}$ & 93.44 & 6.56 & 0.16 & 0.09 & 0.03 & 1.11 & 5.17 \\
& & Mean & $93.43 \pm 0.021$ & $6.575 \pm 0.021$ & $0.17 \pm 0.014$ & $0.095 \pm 0.007$ & $0.025 \pm 0.007$ & $1.115 \pm 0.007$ & $5.17 \pm 0.00$ \\
\hline
\end{tabular}

Keys: MC: Moisture content; ASH: Ash content; FAT: Fat content; CF: Crude fiber; CP: Crude protein and CHO: Carbohydrate

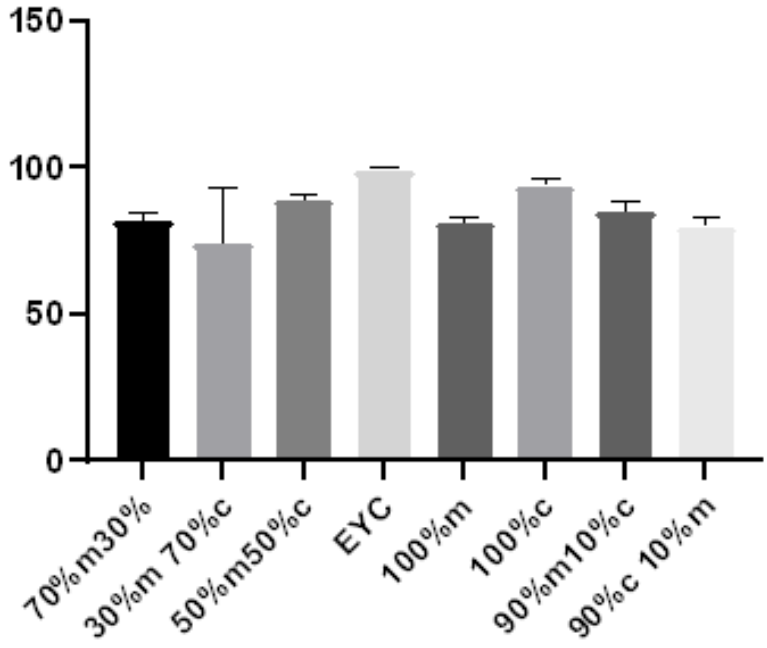

Figure 1: Motility means at zero hour Legend: $Y$ axis- Means of zero hour and $X$ axis- Diluents

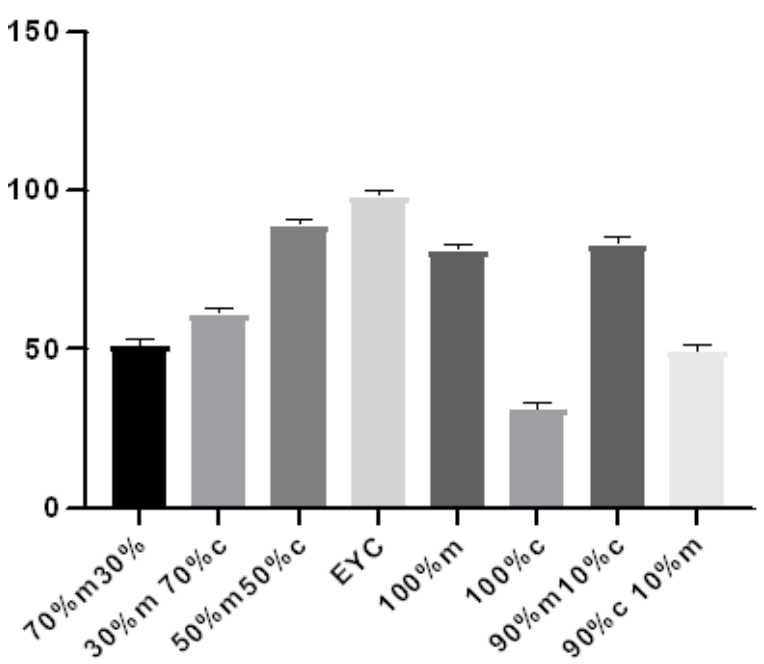

Figure 2: Motility means at one hour Legend: $Y$ axis- Means of zero hour and $X$ axis- Diluents 


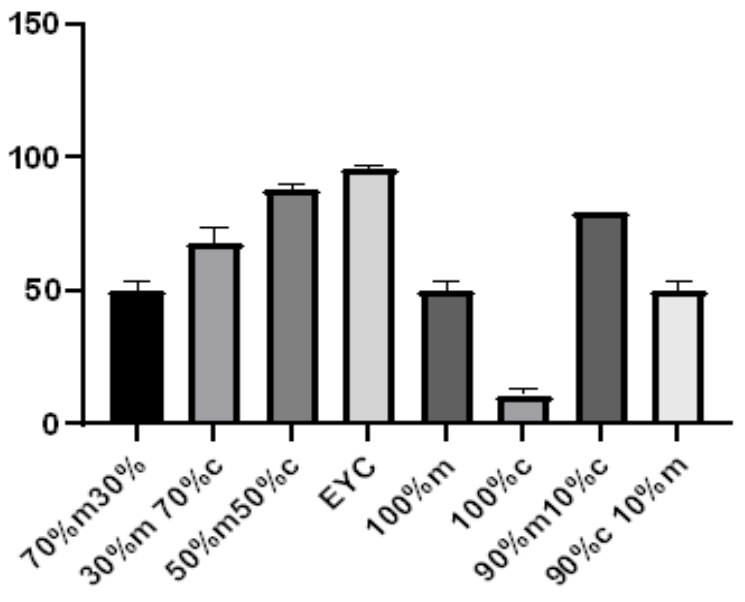

Figure 3: Motility means at two hours

Legend: $Y$ axis- Means of zero hour and $X$ axis- Diluents

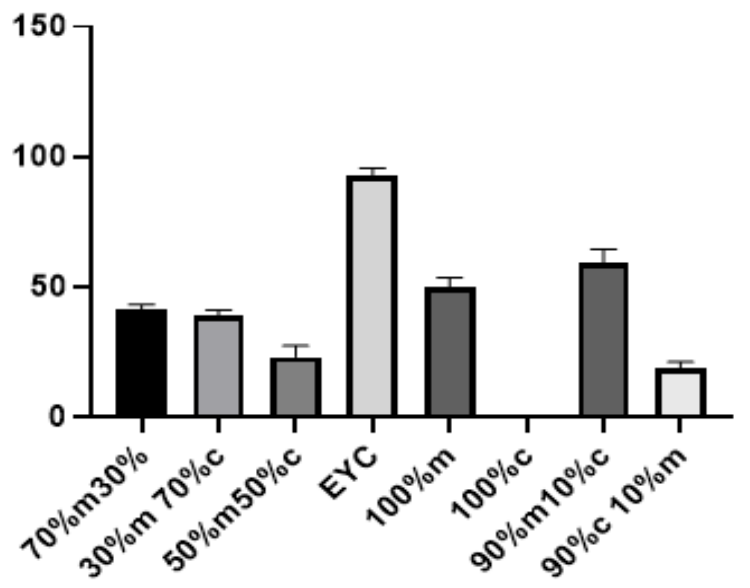

Figure 5: Motility means at four hours

Legend: $Y$ axis- Means of zero hour and $X$ axis- Diluents

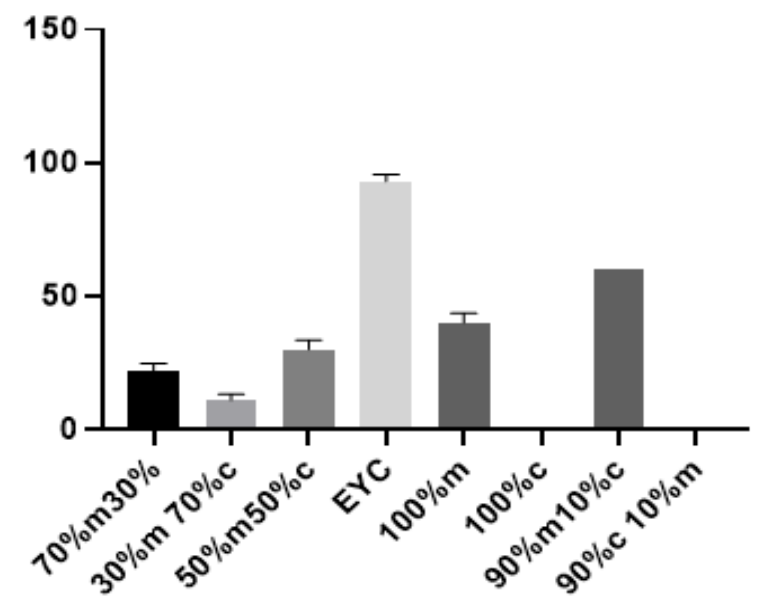

Figure 7: Motility means at six hours

Legend: $Y$ axis- Means of zero hour and $X$ axis- Diluents

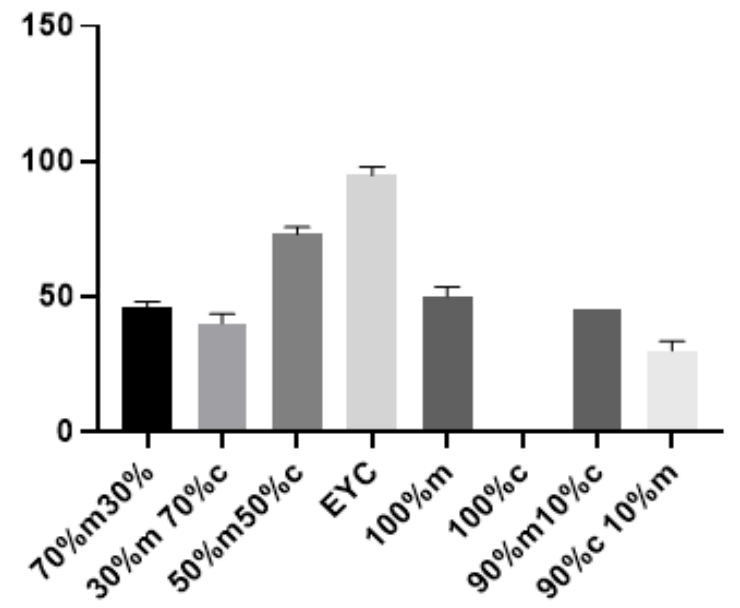

Figure 4: Motility means at three hours

Legend: $Y$ axis- Means of zero hour and $X$ axis- Diluents

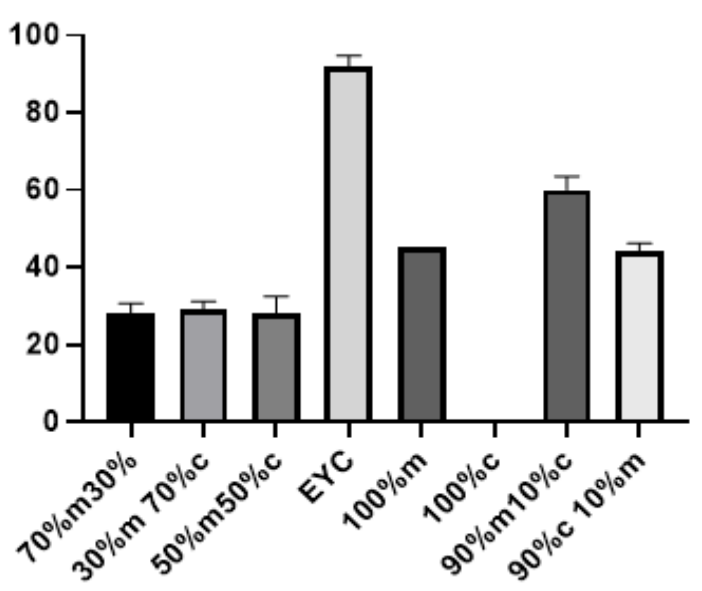

Figure 6: Motility means at five hours

Legend: $Y$ axis- Means of zero hour and $X$ axis- Diluents

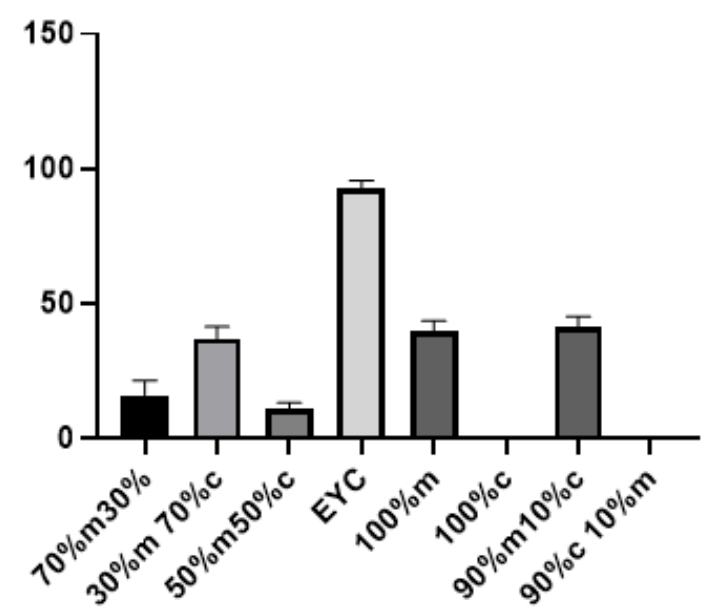

Figure 8: Motility means at seven hours

Legend: $Y$ axis- Means of zero hour and $X$ axis- Diluents 


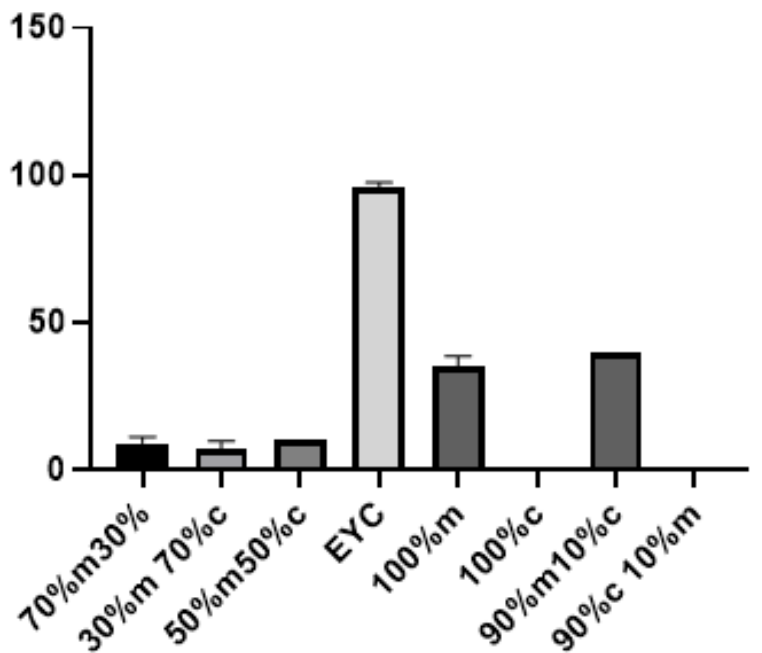

Figure 9: Motility means at eight hours

Legend: $Y$ axis- Means of zero hour and $X$ axis- Diluents

\section{Discussion}

The mean ejaculate volume collected was $0.8 \mathrm{ml}$ and fell within the range of $0.3-1.0 \mathrm{ml}$ reported by Oyeyemi et al. (2009) for West African dwarf ram. The semen colour observed was creamy aligning with the finding of Oyeyemi et al. (2009). The pre-extended motility of the spermatozoa was $94.5 \pm 4.5 \%$ and higher than the value of $83 \%$ obtained by Hossian (2013). The mean pre-extended spermatozoa normality was $93 \pm 2 \%$ and was within the range reported by Robert \& Walker (2007). At zero hour post extension, $100 \% \mathrm{C}$ had a high motility score of $94 \pm 2.24 \%$ which could be attributed to carrot nutrient composition and their antioxidant properties. Also the $\mathrm{pH}$ of $100 \% \mathrm{C}(6.39 \pm 0.06)$ was within the normal range for ram semen (5.9- 7.3.; Singh, 2005). However, there was a drastic drop in motility of this diluent $(100 \% \mathrm{C})$ from zero hour to one hour post extension (31 $\pm 2.24 \%)$ and eventually to three hours post extension at which the score had become $0 \%$. This drastic reduction might have arisen because of the rapid fermentation of carrot juice at room temperature thereby increasing the $\mathrm{pH}$ of the storage medium ultimately becoming spermicidal. At Four to Eight hours post extension, motility values of $100 \% \mathrm{M}$ and $90 \% \mathrm{M} 10 \%$ Cwere better compared with other graded diluents and fell within the range acceptable for successful artificial insemination in the ovine species (30\%) (Robert \& Walker, 2007). At these hours, $90 \% \mathrm{M} 10 \% \mathrm{C}$ appeared better than $100 \% \mathrm{M}$ probably because of the added value of beta carotene provided by $10 \%$ carrot as against its absence in $100 \%$ mango. Also, the fermentation of the $10 \%$ carrot

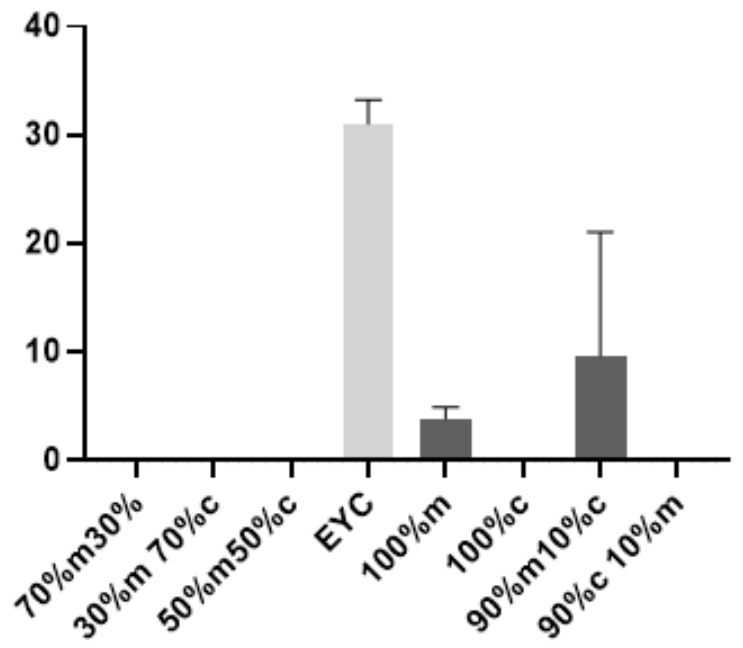

Figure 10: Motility means at nine hours Legend: $Y$ axis- Means of zero hour and $X$ axis- Diluents

could probably be insignificant to cause spermicidal effect in the diluents.

Egg yolk citrate shows good semen keeping quality above all the graded diluents from zero hour to 24 hours post extension as it sustained spermatozoa motility score well into 24 hours post extension (31 $\pm 2.24 \%)$. The ability of the diluents; $100 \% \mathrm{M}$ and $90 \% \mathrm{M} 10 \% \mathrm{C}$ which had more mango to have motility scores comparable to egg yolk citrate up to the eight hour maybe due to its rich carbohydrate content as established from the proximate analysis done for $100 \% \mathrm{M}$ and $90 \% \mathrm{M} 10 \% \mathrm{C}$. This carbohydrate serves as energy source enhancing spermatozoa survival (Sengupta et al., 2020). Mango is also rich in antioxidants, vitamins minerals and phytonutrients which are important for sperm viability. The $\mathrm{pHs}$ of the two diluents were also consistent with the requirement (5.9-7.3) for spermatozoa survivability. However, non-measurement of $\mathrm{pH}$ of the diluents, post-semen extension, is a limitation of this study.

In conclusion, this study shows that a diluent combination of $90 \%$ mango $10 \%$ carrot and a diluent of $100 \%$ mango juice can sustain at room temperature, ram spermatozoa motility up to eight hours post extension, thus recommended for use as semen extenders for the preservation of semen within eight hours of post extension in this specie. However, storage at refrigerator temperature is recommended as this may present better storage compared to room temperature storage.

\section{Conflict of Interest}


The authors declare that there is no conflict of interest.

\section{References}

Akpa GN, Alphonsus C \& Duru S (2006). The relationship between body growth parameters and testicular and horn development in yankasa rams. PAT, 2(2): 56 61.

Aleisa, NA, (2013). Semen characteristics of fertile and subfertile men in a fertility clinic and correlation with age. Journal of King Saud University-Science, 25(1): 63-71.

da Silva Dias, JC (2014). Nutritional and health benefits of carrots and their seed extracts. Food and Nutrition Sciences, 5(22): 2147.

Dossa LH, Sangaré M, Buerkert A \& Schlecht E (2015). Production objectives and breeding practices of urban goat and sheep keepers in West Africa: regional analysis and implications for the development of supportive breeding programs. SpringerPlus, 4(1): 1-12.

Ewuola EO \& Odefemi TR (2019). Growth response, organ morphometry, sperm production and reserve in rabbit bucks administered carrot fruit extracts. Nigerian Journal of Animal Production, 46(1): 30-36.

Hossain RR (2013). Study of Quality of Native Ram: MVSc Thesis, Department of Surgery and Obstertrics, Faculty of Veterinary Science, Bangladesh Agricultural University Mymensingh.

Karagiannidis A, Varsakeli S, Alexopoulos C \& Amarantidis I (2000). Seasonal variation in semen characteristics of Chios and Friesian rams in Greece. Small Ruminant Research, 37(1-2): 125-130.

Katila T, Combes GB, Vamer DD \& Blanchard, TL (1997). Comparison of three containers used for the transport of cooled stallion semen. Theriogenology, 48(7): 1085-1092.

Kheradmand A, Babaei H \& Ali Batavani R (2006). Effect of improved diet on semen quality and scrotal circumference in the ram. Veterinarskiarhiv, 76(4): 333-341.

Kumar DA \& Naqvi SMK (2010). Comparative semen evaluation of malpura and bharatmerion by computer aided sperm analysis technique under semi-arid tropical environment. International Journal of Animal and Veterinary Advances, 2(1): 26-30.
Kusum, M, Verma RC, Renu M, Jain HK \& Deepak S (2018). A review: Chemical composition and utilization of egg. International Journal of Chemical Studies, 6(3): 3186-3189.

Loubser PG \& Van Niekerk CH (1983). Seasonal changes in sexual activity and semen quality in the Angora ram. 2. Semen volume, quality and freezability. South African Journal of Animal Science, 13(3): 161-163.

Mukherjee SK \& Litz RE (2009). Introduction: Botany and Importance. The Mango: Botany, Production and Uses, second edition, CABI, Wallingford, UK. Pp 1-18.

Noakes DE \& Parkinson TJ (2001). Arthur's Veterinary Reproduction and Obstetrics, eight edition. WB Sanders company, Philadelphia United States, Pp 739

Nouri M, Khaki A, Azar FF \& Rashidi MR (2009). The Protective effects of carrot seed extract on spermatogenesis and cauda epididymal sperm reserves in gentamicin treated rats. Yakhteh Medical Journal, 11: 327-333.

Ogbuewu IP (2008). Physiological Responses of Rabbits Fed Graded Levels of Neem (Azadirachta indica A Juss) Leaf Meal. MSc. Thesis, Department of Animal Science and Technology, Federal University of Technology, Owerri, Nigeria. Pp 1-200.

Oloye AA, Omitoogun BA, Ajadi RA, Ola-Davies OE \& Oyeyemi MO, (2019). Comparative survivability and fertility potentials of ovine spermatozoa stored in egg yolk citrate and mixed vegetative extender at room temperature. Bulleting of Animal Health and Production in Africa, 67(4): 313-322

Oloye AA, Oyeyemi MO, Ajala OO \& Akusu MO (2008). Comparative study of fresh coconut milk and standard egg yolk-based semen extenders. Tropical Veterinarian, 26(1\&2): 7-13.

Oyeyemi MO, Olukole SG, Taiwo B \& Adeniji DA (2009). Motility and sperm viability in West African dwarf rams treated with Euphorbia hirta. International Journal of Morphology, 27(2): 459-462.

Robert SY \& Walker RT (2007). Breeding Soundness Examination and Surgical Sterilization of the Ram In: Current Therapy in Large Animal Theriogenology, Second edition, Saunders Elsevier publisher, USA. Pp 620-628.

Sengupta P, Durairajanayagam D \& Agarwal A (2020). Fuel/Energy Sources of Spermatozoa. In: Male Infertility, Springer, Cham. Switzerland Pp 323-335. 
Singh BK (2005). Constituents of seminal plasma In: Textbook of Andrology and Artificial Insemination in Farm Animals, Jaypee Brothers. New Delhi, India. Pp 94-99.

Singh BK, Koley TK, Maurya A, Singh PM \& Singh B (2018). Phytochemical and antioxidative potential of orange, red, yellow, rainbow and black coloured tropical carrots (Daucuscarota subsp. sativusSchubl. \& Martens). Physiology and Molecular Biology of Plants, 24(5): 899-907.

Smith JF (2003). Artificial Insemination of dairy goats. College of Agriculture and Home Economics
Zafar TA \& Sidhu JS (2017). Composition and Nutritional Properties of Mangoes. In Handbook of Mango Fruit: Production, Postharvest Science, Processing Technology and Nutrition, Hoboken New Jersey, United States. Pp 217-236.

Zemjanis R (1977). Collection and Evaluation of Semen in: Diagnostic and Therapeutic Techniques in Animal Reproduction. The Williams and Wilkins Company, Baltimore, Pp 139-180. 